\title{
Faktor Risiko Penyakit Skabies di Masyarakat
}

\section{Risk Factors for Scabies in the Community}

\author{
Heri Purwanto ${ }^{1}$, Retno Puji Hastuti ${ }^{2}$ \\ ${ }^{1}$ Jurusan Kesehatan Lingkungan, Politeknik Kesehatan Tanjung Karang, Indonesia \\ ${ }^{2}$ Jurusan Keperawatan, Politeknik Kesehatan Tanjung Karang, Indonesia
}

\begin{tabular}{l} 
ARTICLE INFO \\
\hline Article history: \\
Received date \\
24 Jan 2020 \\
Revised date \\
17 May 2020 \\
Accepted date \\
26 May 2020 \\
\hline
\end{tabular}

Keywords:

Community;

Risk factors;

Scabies.

\begin{abstract}
ABSTRAK
Scabies is an environmental-based contagious disease caused by mite infection "Sarkopes Scabiei Var Hominis". In the working area of Tanjung Sari Health Center, Natar Subdistrict, during 2014-2015, scabies was in third place in the top 10 contagious diseases. Every month an average of 12 sufferers $(8,33 \%)$ per month are found, distributed in all age groups $(0-5$ years to $\geq 65$ years). This study aims to determine the risk factors for scabies in the community by using a 1: 1 case-control design. Cases are people who have had scabies, while community controls who have never had scabies. The results of the study, the proportion of case and control groups who had risk factors for scabies in sequence: education level $(82,5 \%$ and $68,0 \%)$, living habits $(39,2 \%$ and $17,5 \%)$, physical environment $(45,4 \%$ and $5,2 \%)$, biological environment $(66,0 \%$ and $46,4 \%)$, social environment $(56,7 \%$ and $3,1 \%)$, knowledge $(72,2 \%$ and $36,1 \%)$, attitudes $(12,4 \%$ and $6,2 \%)$, actions $(86,6 \%$ and $52,6 \%$ ), and sanitation $(93,8 \%$ and $42,3 \%)$ There have eight risk factors that statistically show a significant relationship ( $\mathrm{p}$-value $<0,05$ ), i.e. level of education, living habits, physical environment, biological environment, social environment, knowledge, actions, and sanitation factors. Respondents with a bad social environment have a risk of sick scabies 41,03 times greater than respondents with a good social environment, sanitation that does not qualify as a risk of 20,72 times greater than those that meet the required sanitation, a dense physical environment has a risk of 15,28 times greater than the physical environment is not dense.
\end{abstract}

\section{Kata kunci:}

Masyarakat;

Faktor resiko; Skabies.
Penyakit skabies merupakan penyakit menular berbasis lingkungan yang disebabkan oleh infeksi tungau "Sarkopes Scabiei Var Hominis". Di wilayah kerja Puskesmas Tanjung Sari-Kecamatan Natar selama tahun 2014-2015 skabies menempati urutan ketiga dari 10 besar penyakit menular. Setiap bulannya rata-rata ditemukan 12 orang penderita $(8,33 \%)$ perbulan yang terdistribusi pada semua kelompok umur $(0-5$ tahun sampai dengan $\geq 65$ tahun). Penelitian ini bertujuan mengetahui faktor risiko penyakit skabies di masyarakat dengan menggunakan desain kasus-kontrol berpadanan 1:1. Kasus yaitu masyarakat yang pernah sakit skabies, sedangkan kontrol masyarakat yang tidak pernah sakit skabies. Hasil penelitian, proporsi kelompok kasus dan kontrol yang memiliki faktor risiko skabies secara berurutan: tingkat pendidikan (82,5\% dan 68,0\%), kebiasaan hidup (39,2\% dan 17,5\%), Lingkungan fisik (45,4\% dan $5,2 \%)$, lingkungan biologi $(66,0 \%$ dan $46,4 \%)$, lingkungan sosial $(56,7 \%$ dan $3,1 \%)$, pengetahuan $(72,2 \%$ dan $36,1 \%)$, sikap $(12,4 \%$ dan $6,2 \%)$, tindakan $(86,6 \%$ dan $52,6 \%)$, serta sanitasi $(93,8 \%$ dan $42,3 \%)$.Terdapat delapan faktor risiko yang secara statistik menunjukkan hubungan bermakna (nilai $p$-value $<0,05$ ), yaitu tingkat pendidikan, kebiasaan hidup, lingkungan fisik, lingkungan biologi, lingkungan sosial, pengetahuan, tindakan, dan faktor sanitasi. Responden dengan lingkungan sosial tidak baik mempunyai risiko sakit skabies 41,03 kali lebih besar dibandingkan dengan responden yang lingkungan sosial baik, sanitasi yang tidak memenuhi syarat mempunyai risiko 20,72 kali lebih besar dibandingkan yang sanitasi yang memenuhi syarat, lingkungan fisik padat memiliki risiko 15,28 kali lebih besar dibandingkan dengan yang lingkungan fisik tidak padat.

Corresponding Author:

Heri Purwanto ${ }^{1}$, Retno Puji Hastuti ${ }^{2}$

${ }^{1}$ Jurusan Kesehatan Lingkungan, Politeknik Kesehatan Tanjung Karang, Indonesia

2Jurusan Keperawatan, Politeknik Kesehatan Tanjung Karang, Indonesia

Email: ${ }^{1}$ lingkar_pesagi@yahoo.co.id ; ${ }^{2}$ retnopujihastuti15@gmail.com 


\section{PENDAHULUAN}

Penyakit skabies merupakan penyakit menular berbasis lingkungan, yang disebabkan infeksi tungau "Sarkopes Scabiei Var Hominis. Skabies dapat menjangkiti semua orang pada semua umur, ras dan level sosial ekonomi (Raza, et al., 2009).

Skabies hidup di permukaan tubuh inang (ektoparasit), menghisap darah atau mencari makan pada rambut, bulu, kulit dan menghisap cairan tubuh inang. Skabies betina bertelur dan berkembang biak pada terowongan di bawah kulit, menyebabkan reaksi alergi ruam pada kulit berupa macula atau papula kemerahan yang menyebabkan rasa gatal khususnya di malam hari. Selain itu adanya infeksi sekunder setelah infestasi skabies menimbulkan masalah kulit yang lebih parah (Griana, 2013).

Sampai saat ini skabies masih terabaikan sehingga menjadi masalah kesehatan yang umum di seluruh dunia (Heukelbach \& Feldmeier, 2006). Di Afrika seperti Ethiophia, Nigeria masyarakat cenderung mengabaikan penyakit Skabies, karena penyakit ini tidak membahayakan jiwa, sering diabaikan oleh individu yang terkena dampaknya dan tidak memotivasi individu tersebut mendatangi pusat perawatan kesehatan Onayemi, et al. (2005).

Menurut Setyaningrum (2013) Skabies merupakan penyakit kulit yang terabaikan, dianggap biasa saja dan lumrah terjadi pada masyarakat di Indonesia, bahkan di dunia. Hasil survei di beberapa Negara menunjukkan rata-rata prevalensi skabies sebagai berikut: Brazil 9,8\% (Jackson A, dkk, 2007), di India 20,4\% (Baur, 2013),dan Zayyid (2010) di Penang Malaysia prevalensinya $31 \%$ pada anak berusia $10-12$ tahun. Menurut Depkes RI pada tahun 2000 Prevalensi skabies di Indonesia pada tahun 2000 sebesar 4,60-12,95\% dan penyakit skabies menduduki urutan ketiga dari 12 penyakit kulit tersering (Griana, 2013).

Penyakit skabies bersifat menular dan umumnya menyerang sekelompok orang dengan kondisi sosial ekonomi yang rendah, personal hygiene dan sanitasi yang buruk. Infestasi skabies memang tidak membahayakan, namun mengganggu aktivitas dan produktivitas penderitanya, menimbulkan kesan kotor dan terbelakang serta efek psikologis bagi penderita dan masyarakat sekitarnya.

Hasil penelitian Azizah (2011), hasil studi kepustakaan yang penulis lakukan, didapatkan penelitian penyakit skabies umumnya $(>75 \%)$ dilaksanakan di pondok pesantren atau lembaga pendidikan yang mengasramakan muridnya, di sarana pelayanan kesehatan $(>10 \%)$, hanya sebagian kecil yang melakukan penelitian di masyarakat, hal ini sesuai data prevalensi penyakit tersebut di masyarakat termasuk kecil (rata-rata kurang dari 15\%).

Profil kesehatan Provinsi Lampung tahun 2013 dan 2014 dari data 10 besar penyakit menular, tidak diketemukan lagi penyakit skabies (Kementerian Kesehatan RI, 2013; Kementerian Kesehatan RI, 2014). Hal yang sama dengan Profil Kesehatan Kabupaten (Dinas Kesehatan Lampung Selatan, 2014), penyakit skabies tidak lagi masuk 10 besar penyakit di masing-masing kabupaten/kota.

Realita berbeda terlihat di wilayah kerja Puskesmas Tanjung Sari, Kecamatan Natar Lampung Selatan. Selama tahun 2014 setiap bulannya ditemukan penderita skabies, bahkan menjadi urutan ketiga dari 10 besar penyakit menular tahun 2014-Juni 2015. Tahun 2014 ratarata terdapat 12 penderita $(8,33 \%)$ perbulan dengan usia penderita terdistribusi pada semua kelompok umur, mulai kelompok umur 0-5 tahun sampai kelompok $\geq 65$ tahun (Puskesmas Tanjung Sari, 2014).

Hasil analisis deskriptif ditemukan fenomena bahwa distribusi penyakit Skabies tidak tersebar merata, tetapi cenderung mengumpul hanya pada satu dari lima desa di wilayah kerja Puskesmas Tanjung Sari. Prevalensi tertinggi di Desa Tanjung Sari sebanyak 112 orang penderita $(80,09 \%)$, dua desa yang berbatasan langsung yaitu Desa Bumi Sari 20 orang penderita $(9,71 \%)$ dan Desa Muara Putih hanya 9 orang penderita $(4,37 \%)$, Desa Karawang Sari 9 penderita $(4,37 \%)$, terendah Desa Way Sari 3 penderita $(1,46 \%)$ (Puskesmas Tanjung Sari, 2014; Puskesmas Tanjung Sari 2015).

Masih tingginya frekuensi skabies di wilayah Puskesmas Tanjungsari, diperlukan tindakan untuk pengendaliannya dengan memutus mata rantai penularan (faktor risiko) dari penyakit skabies tersebut. Permasalahannya adalah faktor risiko yang apa harus diintervensi dan efektif memberikan dampak menurunkan prevalensi penyakit tersebut? Apabila intervensi dilaksanakan terhadap semua faktor risiko, maka selain tidak efektif juga memerlukan biaya yang besar. Intervensi difokuskan pada faktor risiko yang dampak besar terhadap penurunan penyakit skabies di wilayah tersebut.

Tujuan penelitian diketahuinya faktor risiko dominan yang berhubungan dengan penyakit skabies di masyarakat wilayah kerja Puskesmas Tanjung Sari yang diukur menggunakan rasio odds. 


\section{METODE}

Penelitian menggunakan desain kasuskontrol berpadanan 1:1 (1 kasus dengan 1 kontrol). Kasus adalah masyarakat yang pernah sakit skabies, kontrol, masyarakat yang tidak pernah sakit skabies.

Penelitian dilaksanakan Bulan Juni s.d Oktober 2016, di masyarakat yang berdomisili di wilayah kerja Puskemas Tanjung Sari, Natar Lampung Selatan.

Populasi Kasus, masyarakat di wilayah kerja Puskesmas Tanjung Sari yang sedang atau pernah menderita skabies. Populasi kontrol adalah masyarakat di wilayah kerja Puskesmas Tanjung Sari yang tidak pernah menderita penyakit skabies.

Sampel kasus, masyarakat di wilayah kerja Puskesmas Tanjung Sari yang telah sembuh dari penyakit skabies. Sampel kontrol, masyarakat di wilayah kerja Puskesmas Tanjung Sari yang tidak pernah sakit skabies dan bertempat tinggal 1 (satu) RT dengan kasus.

Kriteria inklusi pada kelompok Kasus, berdomisili menetap (minimal satu tahun), Penderita pertama (jika dalam satu keluarga terdapat lebih dari satu penderita). Sedangkan kelompok kontrol, berdomisili menetap (minimal sudah satu tahun), Tetangga paling dekat rumahnya dengan kasus.

Besar sampel penelitian ini 95 kelompok kasus dan 95 kelompok. Penarikan sampel baik pada kasus maupun kontrol dengan teknik Non probability sampling. Sampel kasus dengan cara mengobservasi, menyeleksi dan memilih dari rekam medis di Puskesmas Tanjung Sari, kemudian diambil seluruh penderita skabies yang telah diberi pengobatan $\geq 1$ satu bulan terhitung dari saat penelitian (penderita sembuh), dimulai dari penderita yang tercatat paling akhir terus ke belakang (tahun 2016, 2015) sampai jumlah 95 sampel kelompok kasus terpenuhi. Sampel kontrol dengan cara mengunjungi rumah kasus, kemudian menentukan kontrol yaitu tetangga kasus yang paling dekat tempat tinggalnya.

Upaya yang ditempuh untuk menjaga kualitas data dan pengukuran :

a. Melatih enumerator (wawancara, mengukur, mengisi kuesioner),

b. Melakukan uji coba kuesioner melibatkan tenaga pengumpul data,

c. Memilih pengumpul data yang relatif setara (mahasiswa Jur. Kesehatan Lingkunngan semester VII),

d. Memperbaiki alat pengumpul data, sehingga mudah dan komunikatif, e. Memilih kontrol berdasar kedekatan tempat tinggal dengan kasus,

f. Menghimbau pengumpul data untuk mengumpulkan data pada setiap kasus dan kontrol oleh pengumpul data yang sama.

Analisis dana dengan analisis bivariat, untuk mengetahui hubungan masing-masing faktor risiko dengan kejadian sakit skabies (Odds Rasio.

Penelitian ini telah mendapatkan Persetujuan Etik (Ethical Clearance) Nomor: LB.02.01/I.1/3119.2/2016 dari Komisi Etik Penelitian Kesehatan Politeknik Kesehatan Tanjung Karang.

\section{HASIL}

Tabel 1. Hubungan Faktor Risiko dengan Penyakit Skabies Menurut Kelompok Kasus dan Kontrol

\begin{tabular}{|c|c|c|c|c|c|}
\hline $\begin{array}{l}\text { Faktor } \\
\text { Risiko }\end{array}$ & Kasus & Kontrol & OR & $\begin{array}{c}95 \% \\
\text { CI }\end{array}$ & $\begin{array}{c}p- \\
\text { value }\end{array}$ \\
\hline \multicolumn{6}{|l|}{ Tingkat } \\
\hline \multicolumn{6}{|l|}{ Pendidikan } \\
\hline$\leq$ Dikdas & 89 & 66 & 2,21 & $1,23-$ & 0,020 \\
\hline$>$ Dikdas & 17 & 31 & & 4,349 & \\
\hline \multicolumn{6}{|l|}{ Kebiasaan } \\
\hline \multicolumn{6}{|l|}{ Hidup } \\
\hline Tdk baik & 38 & 17 & 3,03 & $1,56-$ & 0,001 \\
\hline Baik & 59 & 80 & & 5,89 & \\
\hline \multicolumn{6}{|l|}{ Lingk.Fisik } \\
\hline Padat & 44 & 6 & 15,28 & $5,71-$ & 0,000 \\
\hline Tdk Padat & 53 & 92 & & 40,90 & \\
\hline \multicolumn{6}{|l|}{ Lingk. } \\
\hline \multicolumn{6}{|l|}{ Biologi } \\
\hline Tdk Sehat & 64 & 45 & 2,24 & $1,26-$ & 0,006 \\
\hline Sehat & 33 & 52 & & 4,00 & \\
\hline \multicolumn{6}{|l|}{ Lingk. } \\
\hline Sosial & 55 & 3 & 41,03 & $12,1-$ & 0,000 \\
\hline Tdk baik & 42 & 94 & & 138,7 & \\
\hline Baik & & & & & \\
\hline \multicolumn{6}{|l|}{ Pengetahuan } \\
\hline Tdk baik & 70 & 35 & 4,59 & $2,50-$ & 0,000 \\
\hline Baik & 27 & 62 & & 8,43 & \\
\hline \multicolumn{6}{|l|}{ Sikap } \\
\hline T.mndukung & 12 & 6 & 2,14 & $0,77-$ & 0,138 \\
\hline Mendukung & 85 & 91 & & 5,96 & \\
\hline \multicolumn{6}{|l|}{ Tindakan } \\
\hline Tdk baik & 84 & 51 & 5,83 & $2,87-$ & 0,000 \\
\hline Baik & 13 & 46 & & 11,82 & \\
\hline \multicolumn{6}{|l|}{ Sanitasi } \\
\hline Tidak & 91 & 41 & 20,72 & & \\
\hline memenuhi & & & & $8,26-$ & 0,000 \\
\hline syarat kes. & & & & 51,93 & \\
\hline $\begin{array}{l}\text { Memenuhi } \\
\text { syarat kes. }\end{array}$ & 6 & 56 & & & \\
\hline
\end{tabular}

Berdasarkan tabel 1 diketahui ada delapan variabel faktor resiko yang menunjukkan hubungan yang bermakna dengan penyakit skabies (nilai $p$-value $<0,05$ ), tetapi ada satu variabel yang tidak berhubungan secara signifikan yaitu variabel sikap. 


\section{PEMBAHASAN}

\section{Gambaran Distribusi Kelompok Kasus dan Kontrol}

Distribusi kelompok kasus dan kontrol pada penelitian ini terdapat di empat desa, dengan distribusi tertinggi di Desa Tanjung Sari $(61,9 \%)$, sedangkan ketiga desa lainnya relatif sama (antara 11-14\%).

Diperolehnya kasus dan kontrol yang paling tinggi di Desa Tanjung Sari, dapat menggambarkan akses penderita skabies terhadap Puskesmas Tanjung Sari. Puskesmas Tanjung Sari terletak di Desa Tanjung Sari, sehingga masyarakat di Desa tanjung Sari lebih mudah dalam melakukan pemeriksaan dan pengobatan penyakitnya, hambatan jarak tempuh relatif tidak dialami jika dibandingkan dengan masyarakat desa lainnya.

Selain itu berdasarkan Profil Puskesmas Tanjung Sari, tingkat kepadatan penduduk Desa Tanjung Sari ternyata paling padat $(967,69$ jiwa/ $\left.\mathrm{Km}^{2}\right)$ dibandingkan desa lainnya $(115,05-<$ $\left.967,69 \mathrm{jiwa} / \mathrm{Km}^{2}\right)$. Perbedaan yang sangat besar ini menurut peneliti dapat berpengaruh terhadap peluang terjadinya penularan yang lebih besar, apalagi jika didukung kondisi sanitasi lingkungan yang tidak sehat.

\section{Gambaran Kelompok Kasus dan Kontrol Menurut Faktor Risiko}

Berdasarkan hasil penelitian diketahui kelompok kasus memiliki proporsi eksposure tehadap faktor risiko penyakit skabies secara keseluruhan lebih tinggi dibandingkan dengan kelompok kontrol.

Gambaran tersebut relevan dengan hipotesis penelitian ini, bahwa risiko sakit skabies akan lebih besar dimiliki oleh individu/responden yang memiliki faktor risiko. Dari penelitian ini dapat diidentifikasi bahwa faktor risiko lingkungan lingkungan sosial, sanitasi, dan lingkungan fisik memiliki perbedaan proporsi ekspose pada kasus dan kontrol paling besar, masing-masing secara berurutan beda proporsinya $(53,0 \%, 51,5 \%$, dan $40,3 \%)$.

Hal ini sesuai juga dengan Soemirat 2000) berdasarkan epidemiologi agent penyakit, induk semang yang peka serta lingkungan dan manajemen kesehatan yang buruk merupakan pendorong timbulnya suatu penyakit. Noor (2008) juga menyebutkan bahwa proses timbulnya suatu penyakit akibat suatu proses interaksi antara manusia (pejamu) dengan berbagai sifatnya (biologis, fisiologis, sosiologis, dan antropologis) dengan penyebab (agent) serta lingkungan.

Ma'rufi, et al (2005) menyatakan bahwa kejadian skabies pada manusia banyak dijumpai pada daerah tropis di lingkungan masyarakat yang hidup berkelompok dalam kondisi berdesak-desakan dengan tingkat hygiene, sanitasi dan sosial ekonomi relatif rendah.

\section{Hubungan Faktor Risiko dengan Penyakit Skabies}

Hasil Penelitian pada tabel 1 menunjukkan faktor risiko tingkat pendidikan, kebiasaan hidup, lingkungan fisik, lingkungan biologi, lingkungan sosial, tindakan, dan sanitasi secara statistik memiliki hubungan siknifikan (nilai $p$ value $<0,05$ ) dengan penyakit skabies. Diantara faktor risiko tersebut, didapati faktor lingkungan sosial, sanitasi, dan lingkungan fisik memiliki kekuatan hubungan paling besar dengan nilai OR masing-masing 41,03, 20,72, dan 15,28.

Dengan demikian dapat diartikan bahwa, responden yang memiliki lingkungan sosial tidak baik memiliki risiko terkena penyakit skabies 41,03 kali lebih besar dibandingkan dengan responden yang memiliki lingkungan sosial baik (95\%CI:12,14-138,66). Selanjutnya responden yang fasilitas sanitasinya tidak memenuhi syarat kesehatan juga memiliki risiko sakit skabies 20,72 kali lebih besar dibandingkan dengan responden yang memiliki fasilitas sanitasi memenuhi syarat $(95 \% \mathrm{CI}: 8,26-51,93)$. Demikian pula responden yang tinggal dilingkungan fisik padat, maka akan memiliki risiko sakit skabies 15,28 kali lebih besar dibandingkan dengan responden yang lingkungan fisiknya tidak padat (95\% CI: 5,71-40,90).

Hasil penelitian ini sesuai dengan pernyataan Noor (2008), bahwa lingkungan memegang peranan yang cukup penting dalam menentukan proses terjadinya penyakit. Lingkungan sosial yang meliputi semua bentuk kehidupan sosial budaya, ekonomi, sistem organisasi, serta institusi/peraturan yang berlaku bagi setiap individu yang membentuk masyarakat tersebut. Skabies dapat menular melalui dua cara, yaitu: a) Kontak langsung (direct contact), bibit skabies menular karena kontak badan dengan badan antara penderita dengan orang yang ditulari, b) Kontak tidak langsung (indirect contact), bibit penyakit menular dengan perantara benda-benda terkontaminasi karena telah berhubungan dengan penderita, misalnya: melalui handuk, pakaian, sapu tangan, dan lain sebagainya. 
Hasil penelitian ini juga relevan dengan hasil penelitian Kline, et al. (2013) yang menyebutkan bahwa skabies endemik pada area urban maupun rural dengan lingkungan yang tidak sehat. Menurut Heukelbach (2006). Semakin padat tempat tinggal penduduk atau populasi pada suatu rumah atau lingkungan, maka peluang penularan penyakit skabies akan lebih besar. Hal ini karena interaksi antara agent penyakit skabies, host, dan environment semakin tinggi dan saling mengambil keuntungan, manakala lingkungan atau sanitasi buruk, maka agent akan lebih diuntungkan untuk berkembang biak di tubuh host dan menular kepada host baru lainnya.

Lingkungan sosial memiliki probabilitas paling besar dalam menularkan skabies dari penderita ke host baru yang rentan disusul lingkungan fisik. Hal ini terbukti dengan besarnya odds rasio dari variabel lingkungan sosial dan lingkungan fisik. Hal ini sesuai dengan teori bahwa perpindahan parasit dapat terjadi secara kontak langsung melalui gesekan kulit saat kontak erat. Perpindahan dari pakaian, sprei, handuk terjadi jika barang-barang tersebut terkontaminasi dari penderita yang belum diobati. Skabies juga sangat mudah menular karena kulit yang terkelupas mengandung banyak kutu (Kandun, 2000).

Penularan skabies dapat dikurangi dengan menghindari kontak erat dengan penderita, tidak saling bertukar pakaian atau barang pribadi lainnya dan tetap menjaga kebersihan diri dengan mandi teratur menggunakan sabun.

Faktor resiko dominan kedua dari penelitian yang berhubungan dengan skabies adalah sanitasi lingkungan. Sesuai dengan penelitian Kandun (2000) bahwa penyakit skabies tersebar dan menjadi wabah di seluruh dunia disebabkan oleh buruknya sanitasi lingkungan.

Demikian pula menurut penelitian Ma'rufi et al. (2005) bahwa faktor yang berperan dalam penularan dan tingginya angka prevalensi penyakit Skabies adalah karena sanitasi lingkungan yang buruk. Penyebaran penyakit Skabies dapat dicegah dengan menciptakan sanitasi lingkungan yang baik seperti tersedianya

\section{DAFTAR PUSTAKA}

Azizah I.N. \& Setiyowati W. (2011). Hubungan tingkat pengetahuan ibu pemulung tentang personal hygiene dengan kejadian skabies pada balita di tempat pembuangan akhir kebutuhan sarana air bersih untuk mandi dan mencuci, menjaga kebersihan rumah: karpet, tempat tidur, kasur, bantal dari debu, tungau dan kotoran, menjemur pakaian dengan tetap menjaga personal hygiene untuk mencegah infeksi dan penularan penyakit skabies.

Faktor resiko dominan lain yang berhubungan dengan skabies adalah lingkungan fisik. Yang dimaksud lingkungan fisik adalah kepadatan hunian penduduk. Luas rumah dan kamar tidur yang tidak sebanding dengan jumlah penghuni dalam sebuah rumah tinggal akan menyebabkan over crowded. Kondisi ruangan yang lembab dan kurang mendapatkan sinar matahari akan memudahkan penularan dan penyebaran penyakit infeksi termasuk skabies (Ma'rufi, 2005).

\section{SIMPULAN}

Faktor risiko yang secara statistik menunjukkan hubungan signifikan dengan penyakit skabies yaitu tingkat pendidikan, kebiasaan hidup, lingkungan fisik, lingkungan biologi, lingkungan sosial, pengetahuan, tindakan, dan faktor sanitasi.

Adapun kekuatan hubungan faktor risiko terjadinya penyakit skabies dari yang terbesar ke yang terkecil adalah faktor lingkungan sosial, sanitasi, dan lingkungan fisik. Responden yang memiliki lingkungan sosial tidak baik mempunyai risiko sakit skabies 41,03 kali lebih besar dibandingkan responden yang lingkungan sosialnya baik, sanitasi yang tidak memenuhi syarat mempunyai risiko 20,7 kali lebih besar dibandingkan yang sanitasi yang memenuhi syarat, lingkungan fisik padat memiliki risiko 15,3 kali dibandingkan dengan yang lingkungan fisik tidak padat.

Penelitian ini menggunakan data primer melalui survei ke rumah kasus dan kontrol menggunakan kuesioner. Sehingga masih diterasakan keterbatasan penelitian yaitu menjaga kualitas data karena tidak setaranya sumber informasi (anak-anak dan orang dewasa) yang dapat menyebabkan bias informasi. dan data berasal dari ingatan responden (recall).

kota semarang. Dinamika Kebidanan, vol.1, 1-5: Semarang.

Baur B., Sarkar J., Manna N., \& Bandyopadhyay L. (2013). The Pattern of Dermatological Disorders among Patients Attending the 
Skin O.P.D of A Tertiary Care Hospital in Kolkata. Journal of Dental and Medical Sciences, 3, 1-6: India.

Dinas Kesehatan Lampung Selatan. (2014). Profil Kesehatan Kabupaten Lampung Selatan. Lampung Selatan.

Griana, Tias Pramesti. (2013). Scabies : Penyebab, Penanganan dan Pencegahannya. El-Hayah. 4. 1.9

Jackson A, Heukelbach, J, Feldmeier H. 2007. Transmission of Scabies in Rural Community. Brazilian Journal of Infectious Diseases, Vol.11 no.4 Salvador: Brazil.

Heukelbach, J., Feldmeier, H. (2006). Scabies. Lancet, 367: 1767-1774.

Kandun, I Nyoman. 2000. Manual Pemberantasan Penyakit Menular. Edisi 17. Jakarta.

Kementrian Kesehatan RI. (2013). Profil Kesehatan Indonesia. Jakarta.

Kementrian Kesehatan RI. (2014). Profil Kesehatan Indonesia. Jakarta.

Kline K., James S. McCarthy, Pearson M, Loukas A., \& Hotez P. (2013). Neglected tropical diseases of oceania: review of their prevalence, distribution, and opportunities for control. Plos neglected tropical diseases, 7, 17-55.

Ma'rufi, I. (2005). Faktor Sanitasi Lingkungan yang berperan terhadap prevalensi penyakit scabies. Jurnal Kesehatan Lingkungan. Vol. 2 No. 1. Surabaya.

Noor, Nasry. (2008). Epidemiologi Penyakit Menular. Jakarta: Rineka Cipta.

Onayemi O., Isezuo S.A. \& Njoku C.H. (2005). Prevalence of different skin conditions in an outpatients' setting in north-western Nigeria. International Journal of Dermatology, 44, 7-11: USA.

Puskesmas Tanjung Sari. (2014). Data 10 Besar Penyakit Menular. Tanjung Sari: Pengendalian Penyakit Menular.

Puskesmas Tanjung Sari. (2015). Data 10 Besar Penyakit Menular. Tanjung Sari: Pengendalian Penyakit Menular.

Raza N,. Qadir S. N. R., Agna H. (2009). Risk faktor for scabies among male soldier in Pakistan: case control study. Eastern Mediterranean Health Journal, 15,1-6.

Soemirat, Juli. (2000). Epidemiologi Kesehatan Lingkungan. Yogyakarta: Gajah Mada Press.

Setyaningrum, Yahmi Ira. (2013). Prosiding Seminar Nasional X Pendidikan Biologi, Vol.10, No.1. Malang: Universitas Muhammadiyah Malang.

Zayyid M., Saadah M.S., Adil R., Rohela A.R., \& Jamaiah, I. (2010). Prevalence of skabies and head lice among children in a welfare home in Pulau Pinang, Malaysia. Tropical Biomedicine, Vol 27, 442-446: Malaysia. 